\title{
Reduction of Landscape Pathogens in Florida by Soil Solarization
}

\author{
R. J. McGovern, Plant Pathology Department, and R. McSorley, Entomology and Nematology Department, Uni- \\ versity of Florida-IFAS, Gainesville 32611; and M. L. Bell, SePro Corporation, Carmel, IN 46032
}

\begin{abstract}
McGovern, R. J., McSorley, R., and Bell, M. L. 2002. Reduction of landscape pathogens in Florida by soil solarization. Plant Dis. 86:1388-1395.

Two experiments were conducted during autumn 1997 and 1998 in west-central Florida to evaluate the effectiveness of soil solarization alone and in combination with the biological control agents Streptomyces lydicus (Actinovate) and Pseudomonas chlororaphis (syn. P. aureofasciens, AtEze) and the reduced-risk fungicide fludioxonil (Medallion) in managing soilborne pathogens of impatiens (Impatiens $\times$ wallerana, 'Accent Burgundy'). Naturally infested soil was solarized for 47 or 48 days during September and October using two layers of $25-\mu \mathrm{m}$ clear, low-density polyethylene mulch, separated by an air space of up to $7.5 \mathrm{~cm}$. Solarization decreased the final incidence and progress of Rhizoctonia crown rot and blight, incidence of $P y$ thium spp. in roots, and root discoloration, and increased shoot biomass in both experiments. The technique also consistently reduced root-knot severity and population densities of Meloidogyne incognita, Dolichodorus heterocephalus, Paratrichodorus minor, and Criconemella spp. The incidence of Rhizoctonia crown rot and blight was reduced by fludioxonil, but not by the biological control agents.
\end{abstract}

Additional keywords: bedding plants, biological control, diseases of ornamentals, fungi, nematodes, subtropical climate, sustainable disease management

Root and crown rot and blight caused by Rhizoctonia solani is one of the most common and difficult-to-control diseases in the Florida landscape, affecting over 600 plant species in the state, including commonly used bedding plants such as impatiens (Impatiens $\times$ wallerana; 1 ). Symptoms of the disease may include root rot, necrotic cankers at the soil line, and blighting of shoots and leaves. Equally ubiquitous and damaging to impatiens and many other bedding plants in Florida landscapes are Pythium spp. that cause damping-off and root rot, and Meloidogyne spp. that cause severe root galls and stunting $(1,29,42)$. All three pathogens can cause plant death. Impatiens was chosen as a model landscape plant for evaluation of pest management practices because of its susceptibility

Corresponding author: R. J. McGovern E-mail: rjm@mail.ifas.ufl.edu

This research was supported by the Florida Agricultural Experiment Station, and approved for publication as Journal Series No. R -08467.

The use of trade names in this publication is solely for the purpose of providing specific information. The authors and the University of FloridaIFAS do not guarantee or warranty the products named, and references to them in this publication do not signify our approval to the exclusion of other products of suitable composition.

Accepted for publication 2 August 2002.

Publication no. D-2002-1024-02R

(C) 2002 The American Phytopathological Society to R. solani, Pythium spp., and Meloidogyne spp.

Few options are available to landscape maintenance personnel for preplant reduction of soilborne diseases other than soil removal and application of restricted-use fumigants such as metam sodium or dazomet. Neither of these practices is typically feasible for homeowners. Soil solarization is a sustainable, environmentally compatible practice that has been shown to be effective in reducing many soilborne pests of primarily food crops (20). This technique has been most commonly used in hot, arid to semiarid temperate or tropical regions with limited rainfall and cloud cover during summer (20).

Solarization generally has been effective in managing diseases caused by Rhizoctonia and Pythium spp., but has been more variable in control of root-knot nematodes (26). In addition, results with solarization have been inconsistent in subtropical and tropical locations with frequent rainfall, including peninsular Florida (26). The majority of experiments in Florida have been conducted during the rainy summer months of June through August. Alternatively, we found that solarization conducted in Florida during autumn, a drier yet still relatively hot period, could control Phytophthora nicotianae, another important pathogen of landscape plants (27). However, the temperatures achieved using a single layer of plastic mulch in these experiments would have been insufficient to inactivate more thermostabile pathogens such as $R$. solani except near the soil surface.
It has been shown that using double layers of clear plastic mulch to create an intervening air space achieved higher soil temperatures than single layers when solarization was conducted in the summer $(4,13)$. Separation of two layers of mulch to create a raised tunnel resulted in significant reductions in Fusarium and Pythium spp. and $R$. solani (2). We also observed the increased soil heating of double versus single layers of mulch in central Florida in autumn in a series of unrelated studies (R. J. McGovern, unpublished data). In addition, we believed that two layers of mulch, including a second raised layer, would help to minimize pooling of water following precipitation on beds covered with a single layer.

A number of bacteria have shown promise in reducing diseases caused by $R$. solani, including Bacillus subtilis (41), Pseudomonas spp. (5), and Streptomyces violaceoniger (16). We have observed significant reductions of Rhizoctonia crown rot in greenhouse-grown impatiens by two commercial biological control agents (biocontrols) S. lydicus (Actinovate; Natural Industries, Dallas, TX) and $P$. chlororaphis (syn. P. aureofasciens, AtEze; Eco Soil Systems, Inc., San Diego, CA), and a reduced-risk fungicide, fludioxonil (Medallion; Syngenta Crop Protection, Inc. Greensboro, NC) (25; R. J. McGovern, unpublished data). Previous research also has indicated that certain strains of Pseudomonas and Streptomyces spp. may have the ability to suppress phytopathogenic nematodes (33). P. chlororaphis suppressed populations of the ring nematode ( $\mathrm{Cri}$ conemella xenoplax) in peach roots (23).

The objective of our research was to evaluate the ability of soil solarization in autumn alone and in combination with $S$. lydicus, $P$. chlororaphis, or fludioxonil to reduce Rhizoctonia blight, Pythium root rot, and damage by the root-knot nematode in impatiens.

\section{MATERIALS AND METHODS}

Experimental site. The same field (Eugallie fine sand: 97\% sand, 2\% silt, 1\% clay; $<0.5 \%$ organic matter; $\mathrm{pH} 5.8$ ) at the Gulf Coast Research and Education Center, Bradenton, west-central Florida $\left(27.5^{\circ} \mathrm{N}\right.$, $\left.82.6^{\circ} \mathrm{W}\right)$ was used for two experiments conducted in 1997 and 1998. The site had been planted primarily in vegetable and ornamental crops for the previous 30 years, and had drainage characteristics that allowed the buildup of a wide diversity of phytoparasitic nematodes (30). Natural 
infestation of the field with Rhizoctonia solani and Pythium spp. also was observed in previous experiments with impatiens ( $R$. J. McGovern and R. McSorley, unpublished data).

Solarization and planting. The field was divided into 109.0 - or $9.9-\mathrm{m}^{2}$ plots in 1997 and 1998, respectively, which were separated by at least 9-m buffers. Both experiments utilized a double layer of clear, UV-stabilized, 25- $\mu \mathrm{m}$, low-density polyethylene mulch (DowAgrosciences, Indianapolis, IN). An inner airspace was created by criss-crossing three lengths of 2.5-cm-diameter PVC pipe in the center of the plot between the two mulch layers; the second mulch layer was raised $7.5 \mathrm{~cm}$ in the center of the plot and slanted downward to the plot edges.

The field was cultivated, leveled, and wetted by seep irrigation (semiclosed irrigation conveyed by ditches located on each side of the field) prior to solarization. The experiment was a 2-by-4 factorial using a randomized complete block design with five replications. Five plots were covered with the double mulch and the remaining plots were left nonmulched to test main plot effects (solarization versus nontreated) against soilborne pathogens. Solarization was initiated on 26 August 1997 and 10 September 1998 and continued for 48 and 47 days, respectively. Soil temperatures at 5,15 , and $23 \mathrm{~cm}$ were monitored daily between 2:30 and 3:30 P.M. during both experiments using mechanical soil thermometers.

Following mulch removal, each plot was subdivided into four equal units to test subplot effects (the biocontrols S. lydicus or Pseudomonas chlororaphis, the fungicide fludioxonil, or no treatment) on soilborne pathogens. Main plots were recessed $0.45 \mathrm{~m}$ from the bed margins to avoid planting in inadequately solarized soil resulting from the so-called "border effect" (14). In 1997, 25 6-week-old 'Accent Burgundy' impatiens spaced $5 \mathrm{~cm}$ apart were planted in each subplot; 16 6-week-old impatiens of the same cultivar were used per subplot in 1998. An equal number of nontreated impatiens served as controls in each experiment. Polypropylene shade cloth (30\% light attenuation) was suspended $1.2 \mathrm{~m}$ above each plot for 6 and 4 weeks during 1997 and 1998, respectively, to allow for optimal establishment and growth in the field. Plants were watered by seep irrigation, fertilized once 3 to 4 weeks following planting with a water-soluble fertilizer (Nutricote 20-20-20; Agrivert, Inc., New York) at a rate which furnished $\mathrm{N}$ at $200 \mathrm{ppm}$. Plots were weeded by hand as necessary.

Plant propagation, biocontrol, and fungicide application. Impatiens were initially grown in transplant trays containing a peat-based medium. While in the greenhouse, impatiens were maintained under a constant fertilizer regime that sup- plied the plants with $\mathrm{N}$ at $50 \mathrm{ppm}$ from Nutricote 20-20-20. In 1997, impatiens seedlings initially were treated in the greenhouse with biocontrols by drenching each transplant cell 2 weeks following germination with a $10-\mathrm{ml}$ suspension of Actinovate (product at $1 \mathrm{~g} /$ liter, reported to contain S. lydicus at $1.0 \times 10^{5} \mathrm{CFU} / \mathrm{ml}$ ), or AtEze (product at $5 \mathrm{ml} /$ liter, containing $P$. chlororaphis at $1.0 \times 10^{7} \mathrm{CFU} / \mathrm{ml}$ ). Two weeks later, these biocontrols were reapplied as a 100-ml drench to each impatiens following transplanting into $10-\mathrm{cm}$ plastic pots containing the same peat-based medium. Fludioxonil (Medallion, 36.8 $\mathrm{mg} / \mathrm{liter}$ ) initially was applied to the potted impatiens 6 weeks following germination. In the greenhouse, control plants received equal volumes of water whenever biocontrols and the fungicide were applied. Impatiens were watered-in at planting in the field with $200 \mathrm{ml}$ of the appropriate biocontrol, fungicide, or water alone, and these were reapplied at the same rates 3 weeks later. In 1998, biocontrols initially were applied when impatiens in the greenhouse were transplanted into plastic pots, and reapplied at planting in the field and 3 weeks thereafter. Because of suspected phytotoxicity observed with the fungicide in 1997, Medallion use was limited to an at-planting application in the field, with a follow-up application 3 weeks later.

Viability of biocontrols was determined prior to initial application using amended peptone yeast extract agar (APYEA) consisting of $1 \mathrm{~g}$ of glucose, $5 \mathrm{~g}$ of Bacto Tryptone (Difco Laboratories, Detroit, MI), $20 \mathrm{~g}$ of Bacto Agar (Difco Laboratories), $2.5 \mathrm{~g}$ of yeast extract amended with 1 $\mathrm{g}$ of streptomycin and $0.12 \mathrm{~g}$ of neomycin per liter of deionized water, and King's medium B (22), for $S$. lydicus and $P$. chlororaphis, respectively. Populations of $P$. chlororaphis were ascertained through standard serial dilutions. Adherence of $S$. lydicus to its carrier, zeolite, made serial dilution problematic; therefore, the product was sprinkled on APYEA to confirm viability. Colonization by each biocontrol was assessed following the initial inoculation by placing five root segments from five randomly selected impatiens on the appropriate selective medium after surface disinfestation in $0.5 \% \mathrm{NaOCl}$ for $30 \mathrm{~s}$ followed by a rinse in sterile deionized water (to reduce recovery of extraneous bacteria and fungi). A separate set of root pieces also was rinsed in sterile water alone for additional detection of biocontrols.

Data acquisition. Rhizoctonia crown rot and blight incidence was monitored every 3 days in 1997 and weekly in 1998 during the experiments. Root and crown sections from representative samples were assayed for $R$. solani using a selective medium (39) following surface disinfestation in $0.5 \% \mathrm{NaOCl}$.

Two months after planting, each experiment was terminated and the fresh weight of shoots, root discoloration, root-knot severity, and incidence of root infection by Pythium spp. were evaluated using four randomly selected impatiens plants per subplot. Discoloration was examined in the root systems following water rinses using a 1-to-5 rating scale, where $1=0,2=1$ to $10 \%, 3=11$ to $25 \%, 4=26$ to $50 \%$, and 5 $=51$ to $100 \%$ discoloration. Root-knot severity was determined in the same plants using the 0-to-5 Taylor-Sasser rating scale, where $0=0,1=1$ to $2,2=3$ to $10,3=11$ to $30,4=31$ to 100 , and $5=>100$ galls per root system (40). The incidence of Pythium infection was determined by placing five randomly selected root segments from each root system on a selective medium (17) following surface disinfestation.

Nematode populations in the soil were enumerated and identified before solarization, at planting, and at the conclusion of each experiment. Each soil sample consisted of four to six soil cores $(2.5 \mathrm{~cm}$ in diameter by $20 \mathrm{~cm}$ deep) collected in a systematic pattern from an individual plot using a soil-sampling cone (10). The presolarization and postsolarization sample consisted of six cores per 9.0-by-9.0- $\mathrm{m}^{2}$ (1997) or 9.9-by-9.9- $\mathrm{m}^{2}$ (1998) main plot, and four cores per smaller subplot, taken from plant root zones at the termination of the experiment, respectively. The cores composing a sample were mixed and stored in a plastic bag at $10^{\circ} \mathrm{C}$ for 2 to 3 days prior to extraction. Nematodes then were extracted from a $100-\mathrm{cm}^{3}$ subsample using a modified sieving and centrifugation procedure (18). All individual specimens extracted then were identified and counted using an inverted microscope.

Data analysis. The incidence of Rhizoctonia crown rot and blight was plotted versus time for each experiment, and the development of the disease was evaluated by calculating the area under the disease progress curve (AUDPC). Mean AUDPC, Rhizoctonia blight and Pythium spp. incidence, nematode densities, and shoot fresh weights were compared using an analysis of variance (ANOVA) appropriate for a split-plot design. The existence of subplotmain plot interactions also was routinely tested. Means of disease and plant biomass data were separated by Fisher's protected least significant difference test $(P \leq 0.05)$, using arc sine square root transformation of percentage data where appropriate. Nematode data were transformed by $\log _{10}(x+1)$ prior to analysis. Nontransformed arithmetic means are presented in all tables.

\section{RESULTS}

Experiment 1, 1997. Precipitation occurred sporadically and was detected on only 9 of 48 days during the solarization period in September and October (Fig. 1A). Although cumulative rainfall for September was $38 \%$ above average, most of the precipitation $(75 \%)$ occurred during a 
2-day period, while precipitation for October was $13.2 \%$ below normal (34). Following rain, pooling on the upper mulch layer sometimes caused the temporary, partial collapse of the intervening air space, especially toward the bed edges. This water was physically removed by brushing. Solarization increased soil temperatures compared with nonmulched plots at the three depths monitored (Fig. 1A). The soil temperature at $5 \mathrm{~cm}$ under double mulch reached or exceeded $50^{\circ} \mathrm{C}$ on 17 of 48 days during solarization. The mean soil temperatures recorded between $2: 30$ and 3:30 P.M. in a solarized plot at 5,15 , and $23 \mathrm{~cm}$ (48.4, 42.6, and $34.6^{\circ} \mathrm{C}$, respectively) were increased over a nonmulched control at corresponding depths $(32.2,30.3$, and $28.6^{\circ} \mathrm{C}$, respectively) by 50,40 , and $21 \%$, respectively. Precipitation during the postplant period was generally higher than normal, with a $370 \%$ increase recorded in November, owing to the "El Niño" weather pattern prevalent during the winter of 1997. Immediately following solarization, weed growth was limited to 0.3 to $0.6 \mathrm{~m}$ from the bed edges in solarized plots, but was uniform within nontreated plots.

The density of Pseudomonas chlororaphis in AtEze was determined to be $1.0 \times$ $10^{7} \mathrm{CFU} / \mathrm{ml}$; however, colonization of impatiens roots by the biocontrol could not be confirmed conclusively because fluorescent pseudomonads were detected at an equal incidence in nontreated controls. Viability of S. lydicus was confirmed by growth on PYEA, but colonization of roots by the bacterium could not be confirmed by our methodology. However, colonization by biocontrols could be inferred through growth promotion; impatiens treated with the biocontrols were visibly taller than the nontreated controls prior to transplanting in the field.

No significant main plot-subplot treatment interactions were observed with respect to either the AUDPC or final incidence of Rhizoctonia blight during 1997 (Table 1). Incidence of Rhizoctonia crown rot and blight as measured by the appear- ance of stem lesions and foliar blight was moderate to high and reached $69 \%$ in the nonsolarized control plots 2 months after planting (Table 2). On the other hand, mortality was low and totaled less than $5 \%$ across all treatments (data not shown); typically, infected plants declined through severe loss of individual shoots and roots but seldom died. $R$. solani consistently was isolated from the roots, crown, and stem of symptomatic plants. Solarization significantly decreased the AUDPC for Rhizoctonia blight by $87.9 \%$ and its final incidence by $82.4 \%$ (Table 2). Fludioxonil significantly decreased the final incidence of Rhizoctonia blight but not the AUDPC. Application of neither biocontrol significantly affected Rhizoctonia blight.

In addition to Rhizoctonia blight, root rot or discoloration in impatiens presumably caused, in part, by Pythium spp., also was prevalent at the experimental site. At the termination of the experiment, 2 months after planting, the incidence of root infection by Pythium spp., and the severity
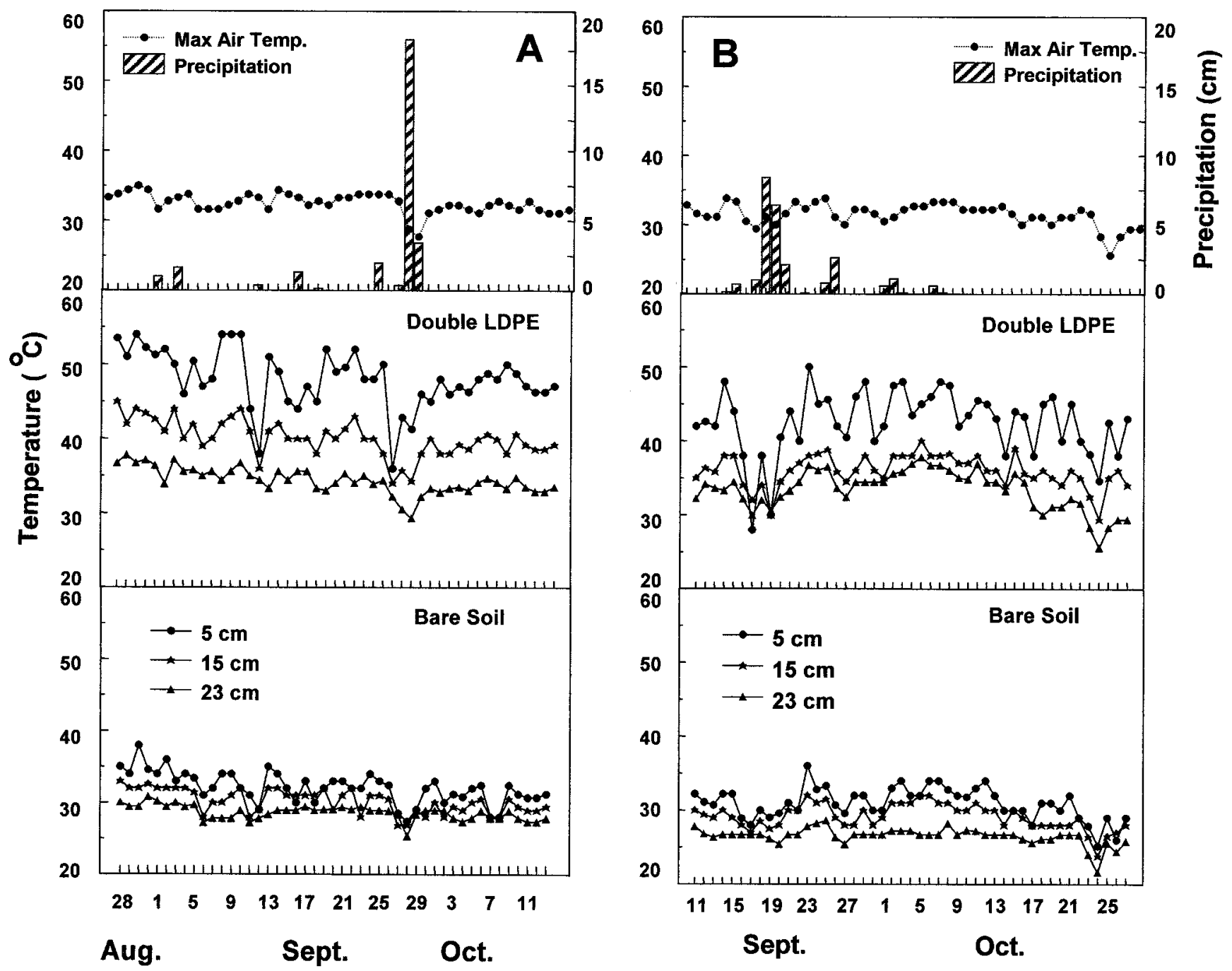

Fig. 1. Effect of soil solarization on the maximum soil temperature recorded under a double layer of low-density polyethylene mulch (LDPE) at 5 , 15, and $23 \mathrm{~cm}$ between 2:30 to 3:30 P.M. in Bradenton, FL during A, 26 August through 13 October 1997 and B, 10 September through 27 October 1998. Ambient temperature and rainfall data were recorded at the Gulf Coast Research and Education Center, Bradenton, FL. 
of root discoloration were significantly lower in solarized than in controls plots, and shoot biomass was significantly higher (Tables 3 and 4). A significant subplotmain plot interaction was observed in root discoloration severity; fludioxonil significantly increased root discoloration in the solarized plots and overall when the subplot effects were averaged across main plots. This increase in root discoloration appeared to be linked to a phytotoxic effect; the three applications of fludioxonil used in this experiment also caused stunting of plants and decreased the fresh weight of shoots. S. lydicus and Pseudomonas chlororaphis had no effect on infection by Pythium spp. or shoot biomass. Root discoloration severity also was not affected by $S$. lydicus. However, Pseudomonas chlororaphis significantly in- creased root discoloration in plants in nonsolarized plots.

Solarization significantly reduced rootknot severity (Table 5), whereas $S$. lydicus, $P$. chlororaphis, and fludioxonil did not affect root galling. No significant differences in the densities of nine plant-parasitic nematodes were noted among plots prior to solarization (Table 6). Fludioxonil and the two biocontrols did not affect nematode populations (data not shown). Because of the absence of significant subplot-main plot interactions, subplots were pooled and main plot effects on nematode densities were analyzed. Populations of five nematodes, including Belonolaimus logicaudatus, Criconemella spp., Dolichodorus heterocephalus, M. incognita, and Paratrichodorus minor, were suppressed immediately following solariza- tion. Two months thereafter, populations of $M$. incognita remained very low in the root zones of impatiens in solarized plots compared with an over eightfold increase in control plants. Solarization also continued to exert a strong suppressive affect on soil densities of $D$. heterocephalus and Pratylenchus spp. at the conclusion of the experiment.

Experiment 2, 1998. Precipitation was detected on only 14 of 47 days during the solarization period in September and October (35). Cumulative rainfall for September was $38 \%$ above the norm, but the bulk of the precipitation $(64 \%)$ occurred during two 2-day periods. Rainfall during October was lower than normal $(-68 \%)$. As in 1997, significant rain events caused temporary sagging of the upper mulch layer, eliminating the inner air space at the bed

Table 1. Main plot (solarization) effects, subplot (biological control agent or fungicide) treatment effects, and main-subplot (main-sub) interaction effects based on analysis of variance (ANOVA) on disease, nematode, and plant performance data from field experiments in Bradenton, FL, in 1997 and 1998x

\begin{tabular}{|c|c|c|c|c|c|c|c|c|c|c|c|c|}
\hline \multirow[b]{3}{*}{ Parameter evaluated $^{\mathrm{z}}$} & \multicolumn{6}{|c|}{$1997^{y}$} & \multicolumn{6}{|c|}{$1998^{y}$} \\
\hline & \multicolumn{2}{|c|}{ Main plot } & \multicolumn{2}{|c|}{ Subplot } & \multicolumn{2}{|c|}{ Main-sub } & \multicolumn{2}{|c|}{ Main plot } & \multicolumn{2}{|c|}{ Subplot } & \multicolumn{2}{|c|}{ Main-sub } \\
\hline & $\boldsymbol{F}$ & $\boldsymbol{P}$ & $\boldsymbol{F}$ & $\boldsymbol{P}$ & $\boldsymbol{F}$ & $\boldsymbol{P}$ & $\boldsymbol{F}$ & $\boldsymbol{P}$ & $\boldsymbol{F}$ & $\boldsymbol{P}$ & $\boldsymbol{F}$ & $\boldsymbol{P}$ \\
\hline Rhizoctonia blight AUDPC & 30.95 & 0.0005 & 2.01 & 0.14 & 0.95 & 0.43 & 13.77 & 0.02 & 14.83 & 0.0001 & 6.36 & 0.002 \\
\hline Rhizoctonia blight final incidence & 25.86 & 0.0009 & 148.38 & 0.0001 & 2.03 & 0.14 & 10.80 & 0.03 & 8.88 & 0.0004 & 2.35 & 0.10 \\
\hline Incidence of Pythium spp. in roots & 12.02 & 0.008 & 1.47 & 0.24 & 1.94 & 0.15 & 5.93 & 0.09 & 1.82 & 0.18 & 3.16 & 0.05 \\
\hline Root discoloration severity & 6.54 & 0.03 & 15.89 & 0.0005 & 5.83 & 0.004 & 21.37 & 0.01 & 2.31 & 0.10 & 1.80 & 0.17 \\
\hline Fresh weight shoots & 170.97 & 0.0001 & 4.11 & 0.0001 & 2.17 & 0.12 & 15.23 & 0.02 & 0.42 & 0.74 & 0.91 & 0.45 \\
\hline Root-knot severity & 5.48 & 0.08 & 0.32 & 0.80 & 0.99 & 0.41 & 7.54 & 0.04 & 0.91 & 0.45 & 0.24 & 0.86 \\
\hline Belonolaimus longicaudatus & $<0.01$ & $>0.40$ & 0.62 & $>0.40$ & 0.62 & 0.40 & 4.92 & 0.09 & 1.13 & 0.36 & 1.13 & 0.36 \\
\hline Mesocriconema spp. & 3.73 & 0.13 & 1.49 & 0.24 & 1.20 & 0.33 & 8.58 & 0.04 & 1.04 & 0.39 & 0.50 & 0.40 \\
\hline Dolichodorus heterocephalos & 32.85 & $<0.01$ & 0.28 & $>0.40$ & 0.12 & $>0.40$ & 38.32 & $<0.01$ & 0.47 & $>0.40$ & 0.48 & $>0.40$ \\
\hline Hemicycliophora spp. & 2.24 & 0.21 & 1.07 & 0.38 & 1.07 & 0.38 & 2.64 & 0.18 & 0.78 & $>0.40$ & 0.68 & $>0.40$ \\
\hline Hoplolaimus spp. & 1.74 & 0.26 & 0.69 & $>0.40$ & 1.22 & 0.23 & 1.14 & $>0.40$ & 1.32 & 0.29 & 1.32 & 0.29 \\
\hline Meloidogyne incognita & 6.84 & 0.06 & 1.41 & 0.26 & 1.71 & 0.29 & 16.83 & 0.01 & 1.21 & 0.33 & 1.21 & 0.33 \\
\hline Paratrichodorus minor & 1.70 & 0.26 & 1.41 & 0.26 & 1.16 & 0.34 & 11.95 & 0.02 & 1.21 & 0.33 & 1.21 & 0.33 \\
\hline Pratylenchus spp. & 6.35 & 0.06 & 0.86 & $>0.40$ & 1.29 & 0.30 & $<0.01$ & $>0.40$ & $<0.01$ & $>0.40$ & $<0.01$ & $>0.40$ \\
\hline Quinisulcius acutus & $<0.01$ & $>0.40$ & 1.00 & $>0.40$ & 1.00 & $>0.40$ & ND & ND & ND & ND & ND & ND \\
\hline
\end{tabular}

$\mathrm{x} \mathrm{ND}=$ not detected.

${ }^{\text {y }} F$ and $P$ values for each experiment.

z ANOVA results for nematode soil population levels were evaluated in December (conclusion of experiment) of each year. AUDPC $=$ area under the disease progress curve.

Table 2. Effect of soil solarization, biocontrols, and a fungicide on the progress and final incidence of Rhizoctonia blight in impatiens 'Accent Burgundy' in a field in Bradenton, Florida in 1997 and 1998x

\begin{tabular}{|c|c|c|c|c|c|c|}
\hline \multirow[b]{2}{*}{ Year, treatment } & \multicolumn{3}{|c|}{ Rhizoctonia blight development (AUDPC) $)^{y}$} & \multicolumn{3}{|c|}{ Final Rhizoctonia blight incidence $(\%)^{\mathrm{z}}$} \\
\hline & Control & Solarized & Subplot means & Control & Solarized & Subplot means \\
\hline \multicolumn{7}{|l|}{1997} \\
\hline Control & $1,956 \mathrm{a}$ & $310 \mathrm{a}$ & $1,132 \mathrm{a}$ & $69.1 \mathrm{a}$ & $20.0 \mathrm{a}$ & $44.6 \mathrm{a}$ \\
\hline Streptomyces lydicus & $1,929 \mathrm{a}$ & $200 \mathrm{a}$ & $1,065 \mathrm{a}$ & $81.2 \mathrm{a}$ & $10.0 \mathrm{a}$ & $45.6 \mathrm{a}$ \\
\hline Pseudomonas chlororaphis & $1,747 \mathrm{a}$ & $183 \mathrm{a}$ & $965 \mathrm{a}$ & $68.7 \mathrm{a}$ & $11.2 \mathrm{a}$ & $40.0 \mathrm{a}$ \\
\hline Fludioxonil & $1,200 \mathrm{a}$ & $136 \mathrm{a}$ & $668 \mathrm{a}$ & $36.2 \mathrm{a}$ & $3.7 \mathrm{a}$ & $20.0 \mathrm{~b}$ \\
\hline Main plot means & 1,708 & $207 * *$ & 63.8 & $11.2 * *$ & & \\
\hline \multicolumn{7}{|l|}{1998} \\
\hline Control & $7,153 \mathrm{~b}$ & $1,013 \mathrm{~b}$ & $4,082 \mathrm{~b}$ & $55.0 \mathrm{ab}$ & $18.8 \mathrm{a}$ & $36.8 \mathrm{~b}$ \\
\hline S. lydicus & $6,814 b$ & $1,024 \mathrm{~b}$ & $3,919 b$ & $48.8 \mathrm{a}$ & $15.0 \mathrm{a}$ & $31.8 \mathrm{~b}$ \\
\hline P. chlororaphis & $10,775 \mathrm{a}$ & $3,137 \mathrm{a}$ & $6,953 \mathrm{a}$ & $72.5 \mathrm{a}$ & $35.0 \mathrm{a}$ & $53.8 \mathrm{a}$ \\
\hline Fludioxonil & $1,177 \mathrm{c}$ & $818 b$ & $997 \mathrm{c}$ & $12.5 \mathrm{c}$ & $10.0 \mathrm{a}$ & $11.2 \mathrm{c}$ \\
\hline Main plot means & 6,479 & $1,497 *$ & $\ldots$ & 46.8 & $19.7 *$ & $\ldots$ \\
\hline
\end{tabular}

${ }^{\mathrm{x}}$ For each year, different letters following means within columns indicate significant differences by Fisher's protected least significant difference test $(P \leq$ 0.05 ), and means within rows are significantly different from the corresponding control by analysis of variance at $*=P \leq 0.05$ or $* *=P \leq 0.01$.

y AUDPC $=$ area under the disease progress curve. Development of Rhizoctonia blight was monitored in 64 to 100 impatiens/plot for 2 months following solarization or no treatment (main plots). Subplots consisted of 16 to 25 plants treated with Streptomyces lydicus (Actinovate), Pseudomonas chlororaphis (AtEze), fludioxonil (Medallion), or nontreated plants.

${ }^{\mathrm{z}}$ Final Rhizoctonia blight incidence was recorded 2 months following solarization. Arc sine square root transformation was used on percentages where appropriate prior to data analysis; nontransformed data are presented. 
edges. Solarization increased soil temperatures compared with nonmulched plots at the three depths monitored; the soil temperature at $5 \mathrm{~cm}$ under double mulch reached or exceeded $45^{\circ} \mathrm{C}$ on 18 of 47 days during solarization (Fig. 1B). The mean soil temperatures recorded between 2:30 and 3:30 P.M. in a solarized plot at 5, 15, and $23 \mathrm{~cm}\left(42.6,36.1\right.$, and $34.1^{\circ} \mathrm{C}$, respectively) were increased over a nonmulched control at corresponding depths (31.0, 29.2 , and $26.6^{\circ} \mathrm{C}$, respectively) by 27,24 , and $28 \%$, respectively. After planting, precipitation was $35 \%$ above and $55 \%$ below normal in November and December, respectively. As in 1997, a border effect indicated by weed growth at the plot margins was evident in solarized plots; weed growth was uniform in control plots.

The density of Pseudomonas chlororaphis in AtEze initially applied was confirmed to be $1.0 \times 10^{7} \mathrm{CFU} / \mathrm{ml}$. Viability of $S$. lydicus was confirmed by growth on PYEA. However, root colonization by both biocontrols could not be confirmed because of overgrowth of the PYEA used for Streptomyces detection by Trichoderma, Fusarium spp., and other fungi, and consistent recovery of fluorescent pseudomonads from both control root pieces and those treated with $P$. chlororaphis. As in the previous experiment, biocontrol colonization could be inferred because of the growth enhancement observed in impatiens transplants following biocontrol treatment.

Incidence of Rhizoctonia crown rot and blight was moderate and reached 55\% in the nonsolarized control plots 2 months after planting (Table 2), whereas mortality was low and, as in 1997, totaled less than $5 \%$ across all treatments (data not shown). $R$. solani consistently was isolated from the roots, crown, and stem of symptomatic plants. Solarization significantly decreased both the AUDPC for Rhizoctonia blight by $76.0 \%$ and final Rhizoctonia blight incidence by $57.9 \%$. Significant subplot-main plot interactions were observed with respect to the AUDPC and its final incidence (Table 1). Fludioxonil significantly decreased the AUDPC and final Rhizoctonia incidence in control plots and overall final incidence of Rhizoctonia blight. Application of $P$. chlororaphis significantly increased the AUDPC in all cases as well as overall final Rhizoctonia blight incidence. Application of S. lydicus did not affect either parameter.

As in 1997, root rot and discoloration were prevalent. Solarization significantly decreased the incidence of root infection by Pythium spp. and the severity of root discoloration, and significantly increased shoot biomass (Tables 3 and 4). Plant growth was reduced noticeably in 1998 compared with 1997, possibly due to reduced soil moisture levels resulting from lower than normal rainfall in late November and early December. Although neither the biocontrols nor fungicide significantly reduced Pythium infection or discoloration in the roots, a significant treatment interaction was observed in the incidence of $P y$ thium spp. detected in plants from nonsolarized plots. Plants in nonsolarized plots treated with S. lydicus or Pseudomonas chlororaphis had a lower incidence of root infection by Pythium spp. than those treated with fludioxonil. Pseudomonas

Table 4. Effect of soil solarization, biocontrols, and a fungicide on the fresh weight of shoots of impatiens 'Accent Burgundy' in a field in Bradenton, Florida in 1997 and $1998^{y}$

\begin{tabular}{lccc}
\hline & \multicolumn{3}{c}{ Fresh weight shoots $(\mathbf{k g})^{\mathbf{z}}$} \\
\cline { 2 - 4 } Year, treatment & Control & Solarized & Subplot means \\
\hline 1997 & & & \\
Control & $0.63 \mathrm{a}$ & $1.76 \mathrm{a}$ & $1.22 \mathrm{a}$ \\
S. lydicus & $0.72 \mathrm{a}$ & $1.90 \mathrm{a}$ & $1.31 \mathrm{a}$ \\
$P$. chlororaphis & $0.72 \mathrm{a}$ & $1.76 \mathrm{a}$ & $1.27 \mathrm{a}$ \\
Fludioxonil & $0.63 \mathrm{a}$ & $1.31 \mathrm{a}$ & $0.95 \mathrm{~b}$ \\
Main plot means & 0.68 & $1.68^{* *}$ & \\
1998 & & & $0.31 \mathrm{a}$ \\
Control & $0.14 \mathrm{a}$ & $0.47 \mathrm{a}$ & $0.34 \mathrm{a}$ \\
S. lydicus & $0.20 \mathrm{a}$ & $0.48 \mathrm{a}$ & $0.32 \mathrm{a}$ \\
$P$. chlororaphis & $0.15 \mathrm{a}$ & $0.52 \mathrm{a}$ & $0.30 \mathrm{a}$ \\
Fludioxonil & $0.12 \mathrm{a}$ & $0.45 \mathrm{a}$ & $\ldots$ \\
Main plot means & 0.15 & $0.48^{*}$ & $\ldots$ \\
\hline
\end{tabular}

${ }^{\text {y }}$ For each year, different letters following means within columns indicate significant differences by Fisher's protected least significant difference test $(P \leq 0.05)$; $*$ and $* *$ indicate that means within rows are significantly different from the corresponding control by analysis of variance at $P \leq 0.05$ or 0.01 , respectively.

${ }^{\mathrm{z}}$ Fresh weight of shoots was assessed 2 months following solarization or no treatment (main plots) using four randomly selected impatiens per subplot. Subplots consisted of 16 to 25 plants treated with Streptomyces lydicus (Actinovate), Pseudomonas chlororaphis (AtEze), fludioxonil (Medallion), or nontreated plants.

Table 3. Effect of soil solarization, biocontrols, and a fungicide on incidence of Pythium infection and severity of root discoloration in impatiens 'Accent Burgundy' in a field in Bradenton, Florida in 1997 and 1998

\begin{tabular}{|c|c|c|c|c|c|c|}
\hline \multirow[b]{2}{*}{ Year, treatment } & \multicolumn{3}{|c|}{ Incidence of Pythium spp. in roots $(\%)^{y}$} & \multicolumn{3}{|c|}{ Root discoloration severity $(\%)^{\mathrm{z}}$} \\
\hline & Control & Solarized & Subplot means & Control & Solarized & Subplot means \\
\hline \multicolumn{7}{|l|}{1997} \\
\hline Control & $97.0 \mathrm{a}$ & $57.0 \mathrm{a}$ & $77.0 \mathrm{a}$ & $43.0 \mathrm{~b}$ & $28.0 \mathrm{~b}$ & $35.5 \mathrm{~b}$ \\
\hline Streptomyces lydicus & $76.0 \mathrm{a}$ & $64.4 \mathrm{a}$ & $70.2 \mathrm{a}$ & $43.8 \mathrm{~b}$ & $30.8 \mathrm{~b}$ & $37.3 \mathrm{~b}$ \\
\hline Pseudomonas chlororaphis & $94.0 \mathrm{a}$ & $50.0 \mathrm{a}$ & $72.0 \mathrm{a}$ & $58.2 \mathrm{a}$ & $30.0 \mathrm{~b}$ & $44.1 \mathrm{~b}$ \\
\hline Fludioxonil & $93.6 \mathrm{a}$ & $80.0 \mathrm{a}$ & $86.8 \mathrm{a}$ & $53.3 \mathrm{ab}$ & $60.8 \mathrm{a}$ & $57.1 \mathrm{a}$ \\
\hline Main plot means & 90.2 & $62.8 * * *$ & 49.6 & $37.4 * *$ & & \\
\hline \multicolumn{7}{|l|}{1998} \\
\hline Control & $51.9 \mathrm{ab}$ & $45.4 \mathrm{a}$ & $48.6 \mathrm{a}$ & $45.0 \mathrm{a}$ & $27.2 \mathrm{a}$ & $36.1 \mathrm{ab}$ \\
\hline S. lydicus & $41.6 \mathrm{~b}$ & $21.6 \mathrm{a}$ & $31.6 \mathrm{a}$ & $43.1 \mathrm{a}$ & $24.2 \mathrm{a}$ & $33.6 \mathrm{ab}$ \\
\hline P. chlororaphis & $34.1 \mathrm{~b}$ & $22.5 \mathrm{a}$ & $28.3 \mathrm{a}$ & $40.0 \mathrm{a}$ & $23.6 \mathrm{a}$ & $31.8 \mathrm{~b}$ \\
\hline Fludioxonil & $73.8 \mathrm{a}$ & $14.2 \mathrm{a}$ & $44.0 \mathrm{a}$ & $55.8 \mathrm{a}$ & $24.2 \mathrm{a}$ & $40.0 \mathrm{a}$ \\
\hline Main plot means & 50.4 & $25.9 *$ & $\ldots$ & 46.0 & $24.8^{* *}$ & $\ldots$ \\
\hline
\end{tabular}

${ }^{\mathrm{x}}$ For each year, different letters following means within columns indicate significant differences by Fisher's protected least significant difference test $(P \leq$ $0.05) ; *, * *$, and $* * *$ indicate that means within rows are significantly different from the corresponding control by ANOVA at $P \leq 0.1,0.05$, or 0.01 , respectively.

${ }^{y}$ Incidence of Pythium infection was determined 2 months after solarization by placing five root segments from four randomly selected plants per subplot on a Pythium-selective medium. Subplots consisted of 16 to 25 plants treated with Streptomyces lydicus (Actinovate), Pseudomonas chlororaphis (AtEze), fludioxonil (Medallion), or nontreated plants. Arc sine square root transformation was used on percentages where appropriate prior to data analysis; nontransformed data are presented.

${ }^{\mathrm{z}}$ Root discoloration was evaluated 2 months following solarization using a 1-to-5 rating scale where $1=0,2=1$ to $10 \%, 3=11$ to $25 \%, 4=26$ to $50 \%$, and $5=51$ to $100 \%$ discoloration. Arc sine square root transformation was used on percentages where appropriate prior to data analysis; nontransformed data are presented. 
chlororaphis also reduced root discoloration compared with fludioxonil when main plot effects were averaged. The biocontrol and fungicide treatments had no significant effect on shoot biomass.

Solarization significantly reduced rootknot severity compared with the nontreated control (Table 5), while S. lydicus, $P$. chlororaphis, and fludioxonil did not affect this parameter. No significant differences in the densities of eight nematodes were noted between plots prior to solarization (Table 7). Fludioxonil or the two biocontrols did not affect nematode populations (data not presented), nor were significant treatment interactions observed (Table 1). Therefore, subplots were pooled and main effects on nematodes were analyzed. Populations of four nematodes, including Criconemella spp., D. heterocephalus, Hemi-

Table 5. Effect of soil solarization, biocontrols, and a fungicide on root-knot severity in impatiens 'Accent Burgundy' in a field in Bradenton, Florida in 1997 and 1998y

\begin{tabular}{|c|c|c|c|}
\hline \multirow[b]{2}{*}{ Year, treatment } & \multicolumn{3}{|c|}{ Root-knot severity $(0 \text { to } 5)^{\mathrm{z}}$} \\
\hline & Control & Solarized & Subplot means \\
\hline \multicolumn{4}{|l|}{1997} \\
\hline Control & $2.60 \mathrm{a}$ & $0.15 \mathrm{a}$ & $1.37 \mathrm{a}$ \\
\hline S. lydicus & $2.40 \mathrm{a}$ & $0.0 \mathrm{a}$ & $1.20 \mathrm{a}$ \\
\hline P. chlororaphis & $2.10 \mathrm{a}$ & $0.25 \mathrm{a}$ & $1.18 \mathrm{a}$ \\
\hline Fludioxonil & $2.55 \mathrm{a}$ & $0.0 \mathrm{a}$ & $1.27 \mathrm{a}$ \\
\hline Main plot means & 2.41 & $0.10^{*}$ & \\
\hline \multicolumn{4}{|l|}{1998} \\
\hline Control & $2.42 \mathrm{a}$ & $0.0 \mathrm{a}$ & $1.21 \mathrm{a}$ \\
\hline S. lydicus & $2.82 \mathrm{a}$ & $0.12 \mathrm{a}$ & $1.47 \mathrm{a}$ \\
\hline P. chlororaphis & $2.52 \mathrm{a}$ & $0.0 \mathrm{a}$ & $1.29 \mathrm{a}$ \\
\hline Fludioxonil & $2.58 \mathrm{a}$ & $0.0 \mathrm{a}$ & $1.20 \mathrm{a}$ \\
\hline Main plot means & 2.58 & $0.03 * *$ & $\ldots$ \\
\hline
\end{tabular}

${ }^{\mathrm{y}}$ For each year, different letters following means within columns indicate significant differences by Fisher's protected least significant difference test $(P \leq 0.05) ; *$ and $* *$ indicate that means within rows are significantly different from the corresponding control by analysis of variance at $P \leq 0.1$ or 0.05 , respectively.

${ }^{z}$ Root-knot severity was assessed 2 months following solarization or no treatment (main plots) in four randomly selected impatiens per subplot using the 0 -to- 5 Taylor-Sasser root-knot rating scale, where $0=0,1=1$ to $2,2=3-10,3=11$ to $30,4=31$ to 100 , and $5=>100$ galls per root system. Subplots consisted of 16 to 25 plants treated with Streptomyces lydicus (Actinovate), Pseudomonas chlororaphis (AtEze), fludioxonil (Medallion), or nontreated plants.

cycliophora spp., and $M$. incognita, were suppressed immediately following solarization. At the termination of the experiment, populations of $M$. incognita remained significantly lower in the root zones of impatiens in solarized plots compared with an over 12-fold increase of the nematode in control plants. Solarization also exerted long-term suppressive effects on Belonolaimus logicaudatus, Criconemella spp., D. heterocephalus, and Paratrichodorus minor.

\section{DISCUSSION}

Solarization conducted during autumn using a double layer of clear plastic mulch was consistently effective in reducing disease in impatiens caused by $R$. solani and Pythium spp., root-knot severity, and densities of $M$. incognita and other phytoparasitic nematodes, and in increasing plant biomass. The suppression of plantpathogenic fungi and enhancement of plant growth observed in our studies conducted in autumn are very comparable to the findings of previous ornamental research evaluating solarization during summer months.

The use of solarization for 6 weeks during July through September produced a 93\% decrease in the incidence of Rhizoctonia bulb rot in field-grown Iris spp., and produced yield increases of 35 to $41 \%$ (6). Solarization of soil or a volcanic ash container medium for 5 to 7 weeks in July and August reduced seedling mortality in Gyp-

Table 6. Effect of solarization on nematode densities in a field planted with impatiens 'Accent Burgundy' in Bradenton, Florida, 1997

\begin{tabular}{|c|c|c|c|c|c|c|}
\hline \multirow[b]{3}{*}{ Nematode (common name) } & \multicolumn{6}{|c|}{ Nematodes per $100 \mathrm{~cm}^{3}$ of soil } \\
\hline & \multicolumn{2}{|c|}{26 August (presolarization) } & \multicolumn{2}{|c|}{14 October (postsolarization) } & \multicolumn{2}{|c|}{12 December (end of experiment) } \\
\hline & Control & Solarized & Control & Solarized & Control & Solarized \\
\hline Belonolaimus logicaudatus (sting) & 1.0 & 0.6 & 2.9 & $0.0^{*}$ & 0.0 & 0.1 \\
\hline Criconemella spp. (ring) & 31.4 & 30.6 & 47.4 & $7.7 * *$ & 19.3 & 10.5 \\
\hline Dolichodorus heterocephalus (awl) & 75.4 & 59.4 & 79.4 & $1.2 * *$ & 36.6 & $1.8^{* *}$ \\
\hline Hemicycliophora spp. (sheath) & 9.0 & 1.4 & 9.9 & 0.0 & 19.9 & 0.0 \\
\hline Hoplolaimus spp. (lance) & 1.0 & 0.2 & 2.9 & 0.2 & 0.8 & 0.1 \\
\hline Meloidogyne incognita (root-knot) & 0.6 & 1.4 & 19.5 & $0.0^{* * *}$ & 170.8 & $1.4 * * *$ \\
\hline Paratrichodorus minor (stubby-root) & 5.0 & 3.4 & 2.6 & $0.1 * * *$ & 6.8 & 3.0 \\
\hline Pratylenchus spp. (lesion) & 2.0 & 3.4 & 1.2 & 0.2 & 0.6 & $0.2 *$ \\
\hline Quinisulcius acutus (stunt) & 0.6 & 0.0 & 0.1 & 0.0 & 0.2 & 0.0 \\
\hline
\end{tabular}

${ }^{\mathrm{z}}$ Data are means of five replications (plots); ${ }^{*}, *$, and $* * *$ indicate differences from corresponding control at $P \leq 0.1,0.05$, and 0.01 , respectively, according to analysis of variance.

Table 7. Effect of solarization on nematode densities in a field planted with impatiens 'Accent Burgundy' in Bradenton, Florida, $1998^{z}$

\begin{tabular}{|c|c|c|c|c|c|c|}
\hline \multirow[b]{3}{*}{ Nematode (common name) } & \multicolumn{6}{|c|}{ Nematodes per $100 \mathrm{~cm}^{3}$ of soil } \\
\hline & \multicolumn{2}{|c|}{10 September (presolarization) } & \multicolumn{2}{|c|}{5 November (postsolarization) } & \multicolumn{2}{|c|}{28 December (end of experiment } \\
\hline & Control & Solarized & Control & Solarized & Control & Solarized \\
\hline Belonolaimus logicaudatus (sting) & 1.4 & 0.8 & 1.2 & 0.0 & 1.0 & $0.0^{* *}$ \\
\hline Criconemella spp. (ring) & 13.2 & 8.8 & 28.4 & $5.8 * * *$ & 10.5 & $2.8 * * *$ \\
\hline Dolichodorus heterocephalus (awl) & 3.2 & 3.4 & 9.0 & $0.0 * *$ & 11.8 & $0.3 * *$ \\
\hline Hemicycliophora spp. (sheath) & 14.0 & 3.2 & 5.4 & $0.0 *$ & 16.1 & 0.1 \\
\hline Hoplolaimus spp. (lance) & 4.2 & 2.0 & 8.6 & 0.1 & 4.4 & 0.0 \\
\hline Meloidogyne incognita (root-knot) & 6.4 & 3.6 & 5.5 & $0.1 * *$ & 68.6 & $0.0 * * *$ \\
\hline Paratrichodorus minor (stubby-root) & 5.4 & 4.8 & 4.9 & 0.1 & 6.5 & $0.2 * * *$ \\
\hline Pratylenchus spp. (lesion) & 1.8 & 1.2 & 1.8 & 0.1 & 0.8 & 0.0 \\
\hline
\end{tabular}

${ }^{\mathrm{z}}$ Data are means of five replications (plots); ${ }^{*}, * *$ and $* * *$ indicate differences from corresponding control at $P \leq 0.1,0.05$, and 0.01 , respectively, according to analysis of variance. 
sophila paniculata attributed to Pythium spp. and $R$. solani by 64 to $100 \%$, and increased yields by 17 to $65 \%$ (11). A $45 \%$ reduction in root discoloration in gerbera (Gerbera jamesonii) coupled with a $250 \%$ increase in cut flower number was observed following solarization of soil infested with $R$. solani, Fusarium spp., and Phytophthora cryptogea (19) during the summer months.

It is interesting to note that the densities of the awl (D. heterocephalus) and rootknot nematodes ( $M$. incognita) were suppressed by solarization during the entirety of our experiments. Another group of researchers found that population reductions of a number of plant-parasitic nematodes were actually greater several months after the completion of solarization for 4 to 6 weeks (36). However, previous research in Florida demonstrated that populations of M. incognita or Paratrichodorus minor initially suppressed by solarization or fumigation rebounded by the termination of subsequent vegetable crops (28). The growing season for impatiens was considerably shorter than for the vegetables used in these previous Florida studies, and may not have been long enough for nematode population increases. Long-term suppression of certain nematodes also may have been the result of suboptimally low soil temperatures for reproduction that occurred during the latter stages of the current experiments. Fall solarization would appear to have merit for short-term and coldtolerant crops that are adversely affected by nematodes.

Soil temperatures achieved using double mulch during September and October in our research were comparable to, or higher than, temperatures recorded under a single layer during July and August, and a similar autumn period at the same site in previous studies (27,31). However, temperatures necessary to rapidly inactivate $R$. solani, Pythium spp., and $M$. incognita, $\geq 50^{\circ} \mathrm{C}$ $(3,32)$, only occurred in the upper soil stratum $(\leq 5 \mathrm{~cm})$ in this research. It is likely that other mechanisms in concert with thermal inactivation were responsible for the disease suppression and enhanced plant growth observed in these experiments. In addition to direct thermal effects, it has been hypothesized that solarization may weaken plant pathogens through sublethal heating resulting in a decreased growth rate or virulence, decreased sporulation, delayed spore germination, increased susceptibility to biological control agents, and so on $(7,24,37)$. Buildup in the soil of volatile compounds, including nitrogenous substances, and thermotolerant pathogen antagonists has been proposed as another mechanism for pathogen reduction by solarization $(37,38)$. Keinath observed that increases in Penicillium spp. accompanied significant decreases in Rhizoctonia belly rot in cucumber in solarized soil (21). Some of the increased growth response following solarization that we and previous researchers have observed may have resulted from an increase in the availability of mineral nutrients (15) or increased activity of plant growth-promoting rhizobacteria (12).

Neither of the commercial biocontrols, Actinovate or AtEze, suppressed $R$. solani, Pythium spp., or phytoparasitic nematodes in their own right or enhanced the effectiveness of solarization despite multiple applications. These biocontrols may have failed to persist in the root systems, may have been out-competed by indigenous bacteria, or, in the case of nematode suppression, may have been inherently ineffective. Surprisingly, in certain instances, application of AtEze actually increased root discoloration, the AUDPC, and final incidence for Rhizoctonia blight. Such unexpected disease enhancement could have been the result of a cultivar-based sensitivity to the biocontrol product or could have represented anomalous results. Biocontrols have proven to be of variable usefulness as an adjunct to solarization. Use of the biocontrol Trichoderma harzianum in combination with solarization enhanced its effectiveness against $R$. solani in potato (Solanum tuberosum) and iris $(6,8)$ but failed to produce a synergistic reduction of the same pathogen in bean (Phaseolus vulgaris) (13). Application of the biocontrols Pseudomonas fluorescens or $T$. harzianum failed to reduce Fusarium wilt in carnation (Dianthus caryophyllus) or to improve the efficacy of solarization against this disease (9).

Fludioxonil (Medallion) consistently reduced the final incidence of Rhizoctonia blight but did not enhance the efficacy of solarization or effect populations of phytoparasitic nematodes. It is clear that the application regime used for this fungicide in the first experiment (one seedling application, two field applications) was deleterious even though it was applied at below the current label rate; root discoloration was significantly increased and biomass decreased by the fungicide. Although impatiens biomass was not significantly decreased by two field applications of fludioxonil in the second experiment, the sensitivity of this cultivar to the fungicide is suggested by numerical increases in Pythium spp. recovery and root discoloration over the control in this experiment.

Our research has demonstrated the utility of soil solarization for reduction of three important soilborne pathogens of landscape plants in Florida. This technique also has a similar potential for such use throughout the southeastern United States, especially when integrated with other effective disease management strategies. Soil solarization, as conducted in these studies, may have most immediate applicability for the management of soilborne pests of landscapes plants in parks and wildlife areas and around schools, homes, and other set- tings where pesticide use is problematic. In a more general context, these results, coupled with previous reduction of Phytophthora nicotianae in Madagascar periwinkle by fall solarization (27), support the expansion of the window for solarization in areas with similar humid, subtropical climates.

\section{ACKNOWLEDGMENTS}

We thank T. Seijo and J. Frederick for providing technical support; and Speedling, Inc., Sun City, FL, for donating plants.

\section{LITERATURE CITED}

1. Alfieri, S. A., Langdon, K. R., Kimbrough, J. W., El-Gholl, N. E., and Wehlburg, C. 1994. Diseases and Disorders of Plants in Florida. Bull. 14, Div. Plant Industry, Fla Dep. Consumer Serv. Gainesville.

2. Annesi, T., and Motta, E. 1994. Soil solarization in an Italian forest nursery. Eur. J. For. Pathol. 24:203-209.

3. Baker, K. F., and Roistacher, C. N. 1957. Principles of heat treatment of soil. Pages 138-161 in: The U. C. System for Producing Healthy Container-Grown Plants K. F. Baker, ed. Calif. Agric. Exp. Stn. Manual No. 23. Univ. Calif. Berkeley.

4. Ben-Yephet, Y., Stapleton, J. J., Wakeman, R. J., and DeVay, J. E. 1987. Comparative effects of soil solarization with single and double layers of polyethylene film on the survival of Fusarium oxysporum f. sp. vasinfectum. Phytoparasitica 15:181-185.

5. Cartwright, D. K., and Benson, D. M. 1995. Comparison of Pseudomonas spp. and application techniques for biocontrol of Rhizoctonia stem rot of poinsettia. Plant Dis. 73:309313.

6. Chet, I., Elad, Y., Kalfon, A., Hadar, Y., and Katan, J. 1982. Integrated control of bulbborne pathogens in iris. Phytoparasitica 10:229-236.

7. Devay, J. E., and Katan, J. 1991. Mechanisms of pathogen control in solarized soils. Pages 87-101 in: Soil Solarization. J. Katan and J. E. Devay, eds. CRC Press, Boca Raton, FL.

8. Elad, Y., Katan, J., and Chet, I. 1980. Physical, biological, and chemical control integrated for soilborne diseases in potatoes. Phytopathology 70:418-422.

9. Elena, K., and Tjamos, E. C. 1997. Evaluation of soil solarization method for control of Fusarium wilt of carnation in the field. Ann. Inst. Phytopathol. Benaki 18:13-24.

10. Esser, R. P., MacGowan, J. B., and Van Pelt, H. M. 1965. Two new nematode subsampling tools. Pl. Dis. Rep. 49:265-267.

11. Gamliel, A., Hadar, E., and Katan, J. 1993. Improvement of growth and yield of Gypsophila paniculata by solarization or fumigation of soil or container medium in continuous cropping systems. Plant Dis. 77:933-938

12. Gamliel, A., and Katan, J. 1991. Involvement of fluorescent pseudomonads and other microorganisms in the increased growth response of plants in solarized soils. Phytopathology 81:494-502.

13. Garibaldi, A., and Tamietti, G. 1989. Solar heating: recent results obtained in Northern Italy. Acta Hortic. 255:125-130.

14. Grinstein, A., Kritzman, G., Hetzroni, A., Gamliel, A., Mor, M., and Katan, J. 1995. The border effect of soil solarization. Crop Prot. 14:315-320.

15. Grunsweig, J. M., Katan, J., Ben-Tal, Y, and Rabinowitch, H. D. 1999. The role of mineral nutrients in the increased growth response of tomato plants in solarized soil. Plant Soil. 206:21-27.

16. Hwang, B. K., Ahn, S. J., and Moon, S. S. 
1994. Production, purification, and antifungal activity of the antibiotic nucleoside, tubercidin, produced by Streptomyces violaceoniger. Can. J. Bot. 72:480-485

17. Jeffers, S. N., and Martin, S. B. 1986. Comparison of two media selective for Phytophthora and Pythium spp. Plant Dis. 70:1038-1043.

18. Jenkins, W. R. 1964. A rapid centrifugalfloatation technique for separating nematodes from soil. Plant Dis. Rep. 48:692.

19. Kaewruang, W., Sivasithamparam, K., and Hardy, G. E. 1989. Use of soil solarization to control root rots in gerberas (Gerbera jamesonii). Biol. Fertol. Soils 8:38-47.

20. Katan, J., and Devay J. E. 1991. Soil solarization: Historical perspective, principles and uses. Pages 23-27 in: Soil Solarization. J. Katan and J. E. Devay, eds. CRC Press, Boca Raton, FL.

21. Keinath, A. P. 1995. Reductions in inoculum density of Rhizoctonia solani and control of belly rot of pickling cucumber with solarization. Plant Dis. 79:1213-1219.

22. King, E. O., Ward, M. K., and Raney, D. E. 1954. Two simple media for the demonstration of pyocyanin and fluorescin. J. Lab. Clin. Med. 44:301-307

23. Kluepfel, D. A., and McInnis, T. M. 1991. Biological control of ring nematodes by Pseudomonas aureofasciens. (Abstr.) Phytopathology 81:1178.

24. Lifshitz, R., Tabachink, M., Katan, J., and Chet, I, 1983. The effect of sublethal heating on sclerotia of Sclerotium rolfsii. Can. J. Microbiol. 29:1607-1610.

25. McGovern, R. J. 1996. Enhanced survival of impatiens in a Rhizoctonia solani-infested medium by biological controls and fungicides. Proc. Fla. State Hortic. Soc. 109:21-23.
26. McGovern, R. J., and McSorley R. 1997. Physical methods of soil sterilization for disease management including soil solarization. Pages 283-313 in: Environmentally Safe Approaches to Crop Disease Control. N. A. Rechcigl and J. A. Rechcigl, eds. CRC Press, Boca Raton, FL.

27. McGovern, R. J., and McSorley, R. 2000. Reduction of Phytophthora blight of Madagascar periwinkle in southwest and west central Florida by soil solarization in autumn Plant Dis. 84:185-191.

28. McSorley, R., M. Ozores-Hampton, P. A Stansly, and J. M. Conner. 1999. Nematode management, soil fertility, and yield in organic vegetable production. Nematropica 29:205-213.

29. Odihirin, R. A., and Jenkins, W. R. 1954. Host-parasite relationship of Impatiens balsamina and certain nematodes. Phytopathology 55:763-766.

30. Overman, A. J. 1985. Off-season land management, soil solarization and fumigation for tomato. Proc. Soil Crop Sci. Soc. Fla. 44:3539.

31. Overman, A. J., and Jones, J. P. 1986. Soil solarization, reaction, and fumigation effects on double-cropped tomato under full bed mulch. Proc. Fla. State Hortic. Soc. 99:315318.

32. Pullman, G. S., Devay, J. E., and Garber, R. H. 1981. Soil solarization and thermal death. A logarithmic relationship between time and temperature for four soilborne plant pathogens. Phytopathology 71:959-964.

33. Siddiqui, Z. A., and Mahmood, I. 1999. Role of bacteria in the management of plant parasitic nematodes: A review. Bioresour. Technol. 69:167-179.

34. Stanley, C. 1998. Weather Report for 1997.
GCREC Bradenton Research Report BRA1998-02. University of Florida-IFAS, Gulf Coast Research and Education Center, Bradenton, FL.

35. Stanley, C. 1999. Weather Report for 1998 GCREC Bradenton Research Report BRA 1999-04. University of Florida-IFAS, Gulf Coast Research and Education Center, Bradenton, FL.

36. Stapleton, J. J., and Devay, J. E. 1983. Response of parasitic and free-living nematodes to soil solarization and 1,3-dichloropropene in California. Phytopathology 73:1429-1436.

37. Stapleton, J. J., and Devay, J. E. 1986. Soi solarization: a non-chemical approach for the management of plant pathogens and pests. Crop Prot. 5:190-198.

38. Stapleton, J. J., Devay, J. E., and Lear, B. 1991. Simulated and field effects of ammonia-based fertilizers and soil solarization on pathogen survival, soil fertility, and crop growth. Pages 331-342 in: Soil Solarization. J. E. Devay, J. J. Stapleton,, and C. L. Elmore, eds. FAO Plant Production Paper 109, FAO, Rome.

39. Sumner, D. R., and Bell, D. K. 1982. Root diseases induced in corn by Rhizoctonia so lani and Rhizoctonia zeae. Phytopathology 72:86-91.

40. Taylor, A. L., and Sasser, J. N. 1978. Biology, Identification and Control of Root-Knot Nematodes (Meloidogyne species). North Carolina State University Graphics, Raleigh.

41. Tschen, S. M. J., Lee, Y. Y., Wu, W. S., and Liu, S. D. 1989. Biological control of basal stem rot of chrysanthemum by antagonists. J. Phytopathol. 126:313-322.

42. Walker, J. T. 1980. Susceptibility of Impatiens cultivars to root-knot nematode, Meloidogyne arenaria. Plant Dis. 64:184-185. 